Played between millions of mouths and a few loaves of bread.

There is a long queue of wandering spirits

Their corpses-at the other side of the river-

Are waiting for somebody to put a coin under their tongue

The greedy boatman is cracking his whip in the smoky air

Look into your pocket, friend-

See if you have a coin

Perhaps this is your father who has spent all

His pennies bribing his way through life

Now frightened by soul-eating dogs he is running around muttering

the Kalb Surah

Look into your pocket, friend,

Even though it might be empty.

Translated by the author

WAN KIN-LAU / HONG KONG

\title{
At an Execution Square in Vietnam
}

one by one heads tumble down the sandbags

they fasten their ears to the earth

and listen to someone

singing an elegy for himself under the grass

the circular loosely stuck on the pole has floated away

in the wind

always

good-looking faces

disappear in mirrors

Translated by the author 